\title{
Physiological and Histopathological Effects of Tributyletin (TBT) on Lymnaea natalensis and Physa acuta.
}

\author{
El-feky F; $\operatorname{Raafat}^{1} \mathrm{H}$ A; and $\operatorname{Kamal}^{1} \mathrm{H}$ \\ Zoology Department, Faculty of Science, Girls Branch Al-Azhar University, Cairo, \\ Egypt, \\ ${ }^{1}$ Zoology Department, Girls Collage for Arts, Science, and Education, Ain-Shams \\ University, Cairo, Egypt.
}

\begin{abstract}
:
Background: Two hermaphrodite snails Lymnaea natalensis and Physa acuta, the most abaundant gastropods in Nile River was investigated to determine the effect of Tributyletin oxide (TBT) on some physiological parameters and histopathological changes in the ovotestis of both snails.

Methods: Nine plastic gars (six treated and three control sets) were used for each species of snails. Every aquaria contained 21 . of dechlorenated water with concentration of $2 \mathrm{ppm}$ of TBT. Samples of heamolymph and ovotestis tissues were taken after 2 and 4 weeks.

Results: The physiological data revealed that the concentration of glucose, cholesterol, calcium, total proteins, albumin, and globulin changed from one species to the other in different responses and according to time of exposure.

The histological data of the hermaphrodite gland or the ovotestis of both snails showed disturbances in differentiation and maturation process, cellular degeneration was also observed.

Conclusion: Due to the hazardous effects of TBT on the physiology and the histology of the ovotestis of both snail species, more research on the impact of TBT or related compounds has to be conducted. The use of TBT as antifouling agent has to be restricted in the developing countries and replace it by related compounds with less or no side effects.
\end{abstract}

\section{Introduction}

During the last decades, the scientists especially marine biologists have been concerned with new type of pollutants associated with antifouling paints known as organotin group (Meador, 1997; Gooding et al., 1999; Hall et al., 2000; Amr, 2004). Tributyltin TBT is one of the most powerful antifouling agents which have been found in sediments and surface water (Fent, 1996). Organotin compounds such as TBT and Triphenyletin (TPT) are used also as stabilizers in plastics, pesticides control of schistosomiasis and antifungal action in textiles and industrial water systems. (Amr, 2004).

Different species of water organisms were severelly affected by TBT toxicity. TBT has been demonstrated to cause impairment in growth, development, reproduction and survival of many marine species (Haggera et al., 2005). Recently, chronic toxicity, growth and reproduction in the freshwater gastropod Lymnaea stagnalis exposed to waterborne TBT over a range of four concentrations in the range of $0-10 \mu \mathrm{g}^{-1}$ has been investigated (Leung et al., 2007). They observed that egg development was completely inhibited at $10 \mu \mathrm{g} \mathrm{l}^{-}$

The major mode of action of TBT as other organotin group is that they act as hormonal disruptor for many marine organisms, especially mollusca (Gibbs and Bryan, 1996a). This hormonal disruption includes the development of male organs in gastropod females. This syndrome is known as imposex which can lead to sterilization and finally death. (Bech 2002; Marshall and Rajkumar, 2003 and Terlizzi et al., 2004).

Imposex is thought to be irreversible and normal egg lying can be prevented and ultimately results in a population decline (Bryan et al., 1986).

In some species, imposex is typically induced by TBT and TPT. Only a few reports, however, have presented evidence for population level effects of reproductive failure due to imposex. 
Such evidence has been based on either morphological or histological methods (Ide et al., 1997).

In 2006, Toshihiro et al., suggested that reproductive failure (suppressed ovarian maturation and ovarian spermatogenesis) in adult Babylonia japonica accompanied with imposex induced by TBT and TPT which brought marked decline in the snail population.

Sex steroid hormones such as testosterone and $17 \quad \beta \quad$ estradiol are important physiologically in the development of sex organs and maturation of gonads in vertebrates. Thus, similar sex steroid hormones might also regulate the reproduction of invertebrates such as gastropods (Le Blanc, 1999).

Aromutase, the enzyme responsible for the conversion of testosterone to estradiol-17B $\left(\mathrm{E}_{2}\right)$, was found to be inhibited by TBT (Heidrich et al., 2001). Other studies showed other mechanisms of action in gastropods such as reducing of steroidogenesis or increasing of neuropeptide secretion (Marcillo and Porte, 1999).

In some publications TBT and TPT were used as biomarkers devised to measure molecular damage, developmental abnormality and physiological impairment combined with chemical analysis to determine the effects of pollution at different sites (Galloway et al., 2004).

Puccia et al. (2001) studied the relative impact of TBT chloride as one of the environmental pollutants using Ciona intestinalis ovary as a model system. They found that the effects of TBT exposure are concentration dependent and include a decrease of ATP levels, lipids content, and nucleic acid content. In contrast, a marked increase in calcium $\left(\mathrm{Ca}^{+2}\right)$ and glucose content was observed.

Since TBT and TPT act as hormonal disruptors, all the antistress responses start at the sub cellular level, and usually include the disruption of normal metabolic

\section{Material and Methods:}

Adult freshwater snails Lymnea natalensis and Physa acuta (> $20 \mathrm{~mm}$ in shell length) were collected from waters of irrigation channels and strains in Abou Rawash villages of Giza Governorate. The snails pathway. These responses imply an energetic cost that interferes with the energetic budget for other vital process, such as growth and reproduction (Widdows and Dankin, 1992).

Glycogen level is one of the parameters that reflects the energetic and reserves status of organisms. Moreover, glycogen is used rapidly when organisms are under stress, and levels of this energy reserve have been suggested as useful biomarker of general stress (Hugget, et al., 1992; and Vasseur and Cossu-Leguille, 2003).

Lira et al. (2000) observed an increase in the total proteins concentration in the hemolymph of $B$. similaris at day 10 of starvation, when this value was $198 \%$ higher than that observed in the hemolymph of the fed snails and turning to values near to that of the control group at the end of the period of starvation analyzed (30 days).

Recently, it has become apparent that the growth of snails, due to their high-Ca requirements for shell formation, might be sensitive to metal exposure, especially when the metal interferes with $\mathrm{Ca}$ homeostasis (Grosell and Brix, 2004). They also suggested that the inhibition of $\mathrm{Ca}$ uptake by metals could potentially impair snail growth if $\mathrm{Ca}$ influx would become limiting for growth of the shell which consists almost entirely of $\mathrm{CaCO}_{3}$.

Consequently, continued research of organotin compounds remains necessary due to the lack of toxicity data generated with fresh water organisms.

The present study was designed to determine the relative toxicity of TBT against two species of freshwater snails Physa acuta and lymnaea natalensis. Histopathological study was done on the gonads of both snails. Physiological study was also designed to determine the effect of TBT on the levels of glucose, cholesterol, calcium, total proteins, albumin and globulin in the heamolymph of both snails.

were kept in well aerated glass aquaria, each of them containing $3 \mathrm{~L}$ of dechlorinated tap water for at least $96 \mathrm{~h}$. to acclimatize them to laboratory conditions. The snails were fed on dried or fresh lettuce. The water was changed daily and dead snails were removed as soon as possible. 


\section{Preparation of stock solution of TBT:}

The stock solution was prepared in the presence of absolute alcohol as primary solvent. $10 \mu \mathrm{l}$ of tributyltin oxide TBT was taken and added to $10 \mathrm{ml}$ of absolute alcohol and complete the solution to 1000 $\mathrm{ml}$ by adding tap water to give a concentration of $10 \mathrm{ppm}$. Prepared solution was stored in clean, dry and black bottle at room temperature.

Experimental design: Nine plastic gars (six treated and three control sets) were used for each species of snails. Every aquaria contained $2 \mathrm{~L}$ of dechlorinated water and 2ppm of TBT for both snail sp. Samples of heamolymph were taken after two and four weeks for measuring various biochemical parameters. Glucose content was measured according to Keilin and Hartree (1945). Cholesterol content was measured according to Richmond (1973).

Calcium was measured according to Cowley et al. (1987).

Total proteins, globulin, and albumin heamolymph content were measured according to the method of Doumas (1975). Ovotestis of the treated and control groups of the two snail species were dissected after two and four weeks of treatment for histological study. After a 2-h Bouin's fixation, each piece of gonad was stored in $70 \%$ ethanol. Following dehydration through increasing alcohol concentrations, tissues were embedded in paraffin wax. Sections were cut and stained with haematoxylin and eosin as a basic stain (Harris, 1990).

\section{Results:}

Physiological Results:

Data in table, 1 and figure, 1 represent the results of the effect of TBT after two and four weeks on some physiological parameters. The results showed that, after exposure to two weeks the concentration of glucose decreased in both Physa and Lymnea snails to be $6.66 \pm 1.500 \mathrm{mg} / \mathrm{ml}$ and increased in physa snails after exposure for four weeks to reach $20.0 \mathrm{mg} / \mathrm{ml}$ and increased also in lymnea to return to the control value with concentration of 13.330 $\pm 1.400 \mathrm{mg} / \mathrm{ml}$

The concentration of cholesterol increased in both snails Physa and Lymnea after two weeks of exposure to reach $16.220 \pm 1.300$ $\mathrm{mg} / \mathrm{ml} \& 21.620 \pm 1.300 \mathrm{mg} / \mathrm{ml}$ respectively, and then decreased after four weeks of exposure to $5.410 \pm 1.000$ in both snails.

The exposure of snails to TBT for 2 weeks showed a significant increase of calcium in Physa snail $43.680 \pm 1.500 \mathrm{mg} / \mathrm{ml}$ after two weeks of exposure which decreased to $21.580 \pm 1.200 \mathrm{mg} / \mathrm{ml}$ after four weeks of exposure compared with control. In the same time calcium concentration in Lymnea significantly decreased to $12.110 \pm$ $1.800 \mathrm{mg} / \mathrm{ml}$ after two weeks of exposure and continues its decline after four weeks of exposure to be $10.530 \pm 1.200 \mathrm{mg} / \mathrm{ml}$.

The total proteins concentration of Physa snail have not changed compared with the control group $0.476 \pm 0.080 \mathrm{mg} / \mathrm{ml}$ after two weeks of exposure and highly increased to $0.952 \pm 0.080$ after four weeks of exposure. In Lymnea snails a depletion of total proteins occurred after exposure to two weeks to be $0.238 \pm 0.050$. concentration highly increased to $0.861 \pm 0.030$ in Physa and returned to the control value in Lymnea

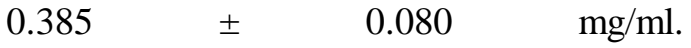




\section{El-feky et al}

\begin{tabular}{|c|c|c|c|c|c|c|c|c|c|c|c|c|}
\hline & & \multicolumn{3}{|c|}{ Control } & \multicolumn{3}{|c|}{ Tr.W } & \multicolumn{3}{|r|}{ Tr.W 4} & \multicolumn{2}{|r|}{ T-test } \\
\hline Status & & Mean & \pm & SD & Mean & \pm & SD & Mean & \pm & SD & $\mathbf{P}_{1}$ & $\mathbf{P}_{2}$ \\
\hline \multirow[b]{2}{*}{ lucose } & $y s a \mathrm{sr}$ & 3.330 & \pm & 400 & 660 & \pm & 200 & .000 & \pm & 500 & .003 & .005 \\
\hline & $\begin{array}{c}\text { Lymnaea } \\
\text { snail }\end{array}$ & 13.330 & \pm & 1.700 & 6.660 & \pm & 1.200 & 13.330 & \pm & 1.400 & 0.003 & 1.000 \\
\hline \multirow[b]{2}{*}{ Cholesterol } & Physa snail & 10.810 & 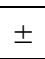 & 200 & 5.220 & \pm & 1.300 & 5.410 & \pm & 1.000 & .006 & 0.00 \\
\hline & $\begin{array}{c}\text { Lymnaea } \\
\text { snail }\end{array}$ & 16.220 & $=$ & .500 & 1620 & \pm & .300 & 5.410 & \pm & 1.100 & 0.009 & 00 \\
\hline \multirow[b]{2}{*}{ Calcium } & aysa snail & 6.840 & \pm & 2.000 & 43.680 & \pm & 1.500 & 21.580 & \pm & 1.200 & 0.000 & 0.018 \\
\hline & $\mathbf{s}$ & 0 & \pm & 300 & 12.110 & \pm & 00 & 0 & \pm & 200 & 001 & .000 \\
\hline \multirow{2}{*}{$\begin{array}{r}\text { Total } \\
\text { Proteins }\end{array}$} & Physa snail & 6 & + & 0.080 & 476 & \pm & 0.100 & 0.952 & \pm & 0.080 & .000 & 0.00 \\
\hline & $\begin{array}{r}\text { Lymr } \\
\text { S }\end{array}$ & 0.470 & \pm & 0.060 & 0.238 & \pm & 0.050 & 0.476 & \pm & 0.090 & 0.007 & 0.928 \\
\hline \multirow[b]{2}{*}{ Albumin } & Physa snail & 1 & \pm & 0.008 & 73 & \pm & 0.080 & 0.091 & \pm & 100 & 017 & 1.00 \\
\hline & $\begin{array}{c}\text { Lymnaea } \\
\text { snail }\end{array}$ & 201 & \pm & 0.007 & 0.182 & \pm & 0.080 & 0.091 & \pm & 0.100 & 0.121 & 1.000 \\
\hline \multirow[b]{2}{*}{ Globulin } & Phys & 0.385 & \pm & 0.060 & 203 & \pm & 0.050 & 0.861 & \pm & 0.030 & 0.016 & 0.000 \\
\hline & $\begin{array}{c}\text { Lymnaea } \\
\text { snail }\end{array}$ & 0.385 & \pm & 0.080 & 0.056 & \pm & 0.090 & 0.385 & \pm & 0.060 & 5.268 & 1.000 \\
\hline
\end{tabular}

Table 1: Effect of TBT on glucose, cholesterol, calcium, total proteins, albumin, and globulin after two and four weeks
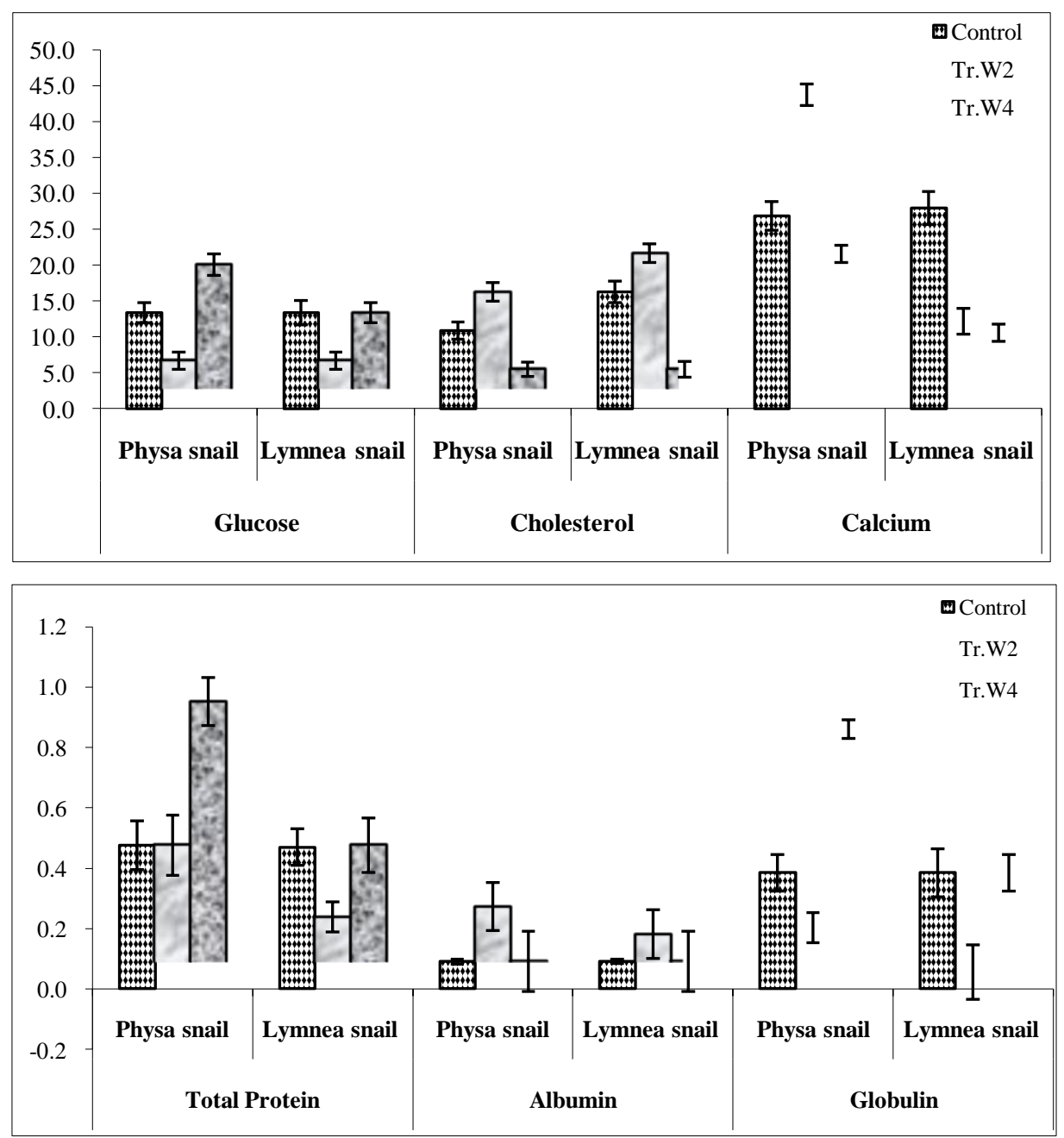


\section{El-feky et al}

\section{Histological results}

The ovotestis of Lymnea natalensis and Physa acuta consists of large number of vesicles known as acini. Each acinus is enveloped in a sheath of squamous epithelium and thin connective tissue. Large vascular connective tissue lies between the acini and the covering epithelium of the mantle. In each acinus both male and female reproductive gametes are produced. Plate 1,2(A) are showing the ovotestis of control Lymnaea natalensis and Physa acuta. Each acinus possesses a number of immature oocysts, a few mature ova at the periphery and bundles of sperms in the center of the acinus. Two weeks of exposure of the ovotestis of snail Lymnaea resulted in degeneration of most of the sperms beside fine observable histopathological changes in ova (Plate 1, b). After four weeks of exposure (Plate 1, c) marked degenerative effects in both sperms and most of the ova were showed, and the epithelial sheath was invaginated.

Plate ( 2 b) showed ovotestis of snail physa after two weeks of exposure where degeneration in both sperms and ova was observed. Four weeks of exposure (Plate $2, \mathrm{c})$ showed sever disruption of germ cells and more degenerative effect (tissue necrosis) in all the contents of acini. Epithelial tissue was invaginated and some acini seemed to be empty.

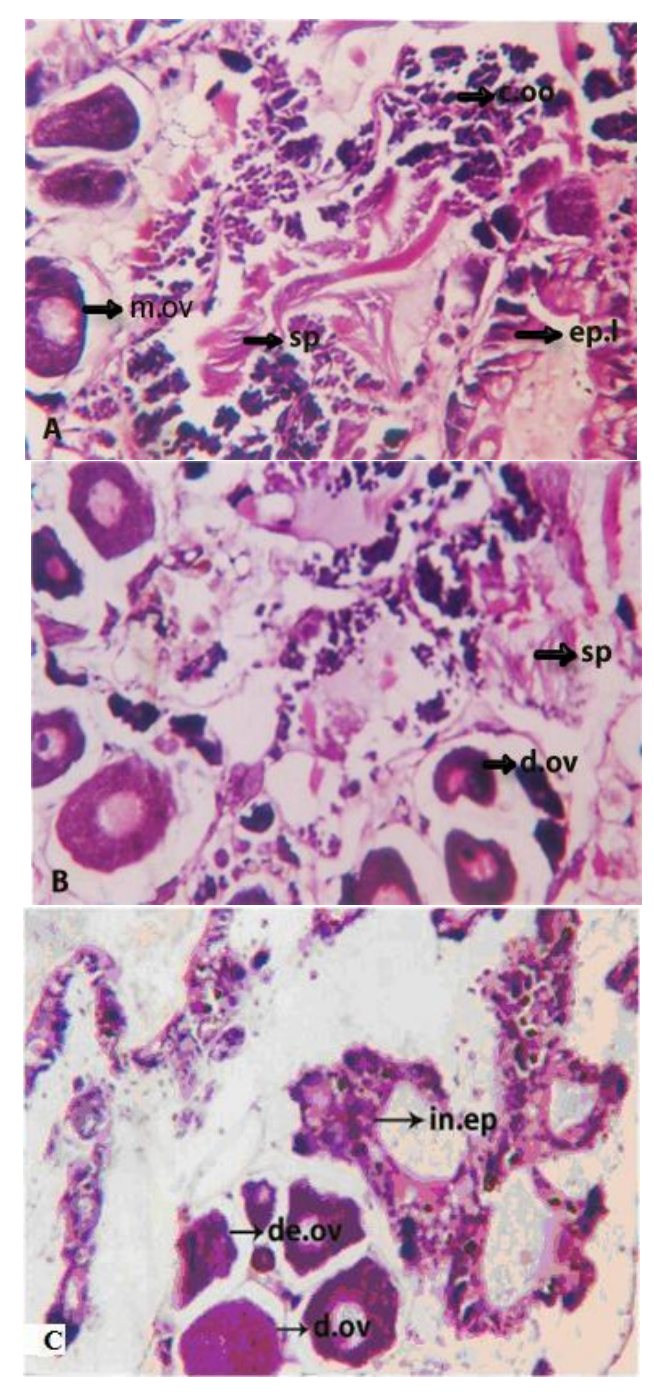

Plate 1: Sections of ovotestis of Lymneae natalynsis

A- Control, showing mature ovum (m.ov), cluster of oogonia(c.oo), sperms(sp), and epithelial lining (ep.1.).

B- Exposure to TBT for two weeks showed degenerated ovum (d.ov). 
C- Exposure to TBT for four weeks showed invaginated epithelium (in.ep),degenerated and atrophied, ovum (de.ov.), and dead ovum (d.ov.).

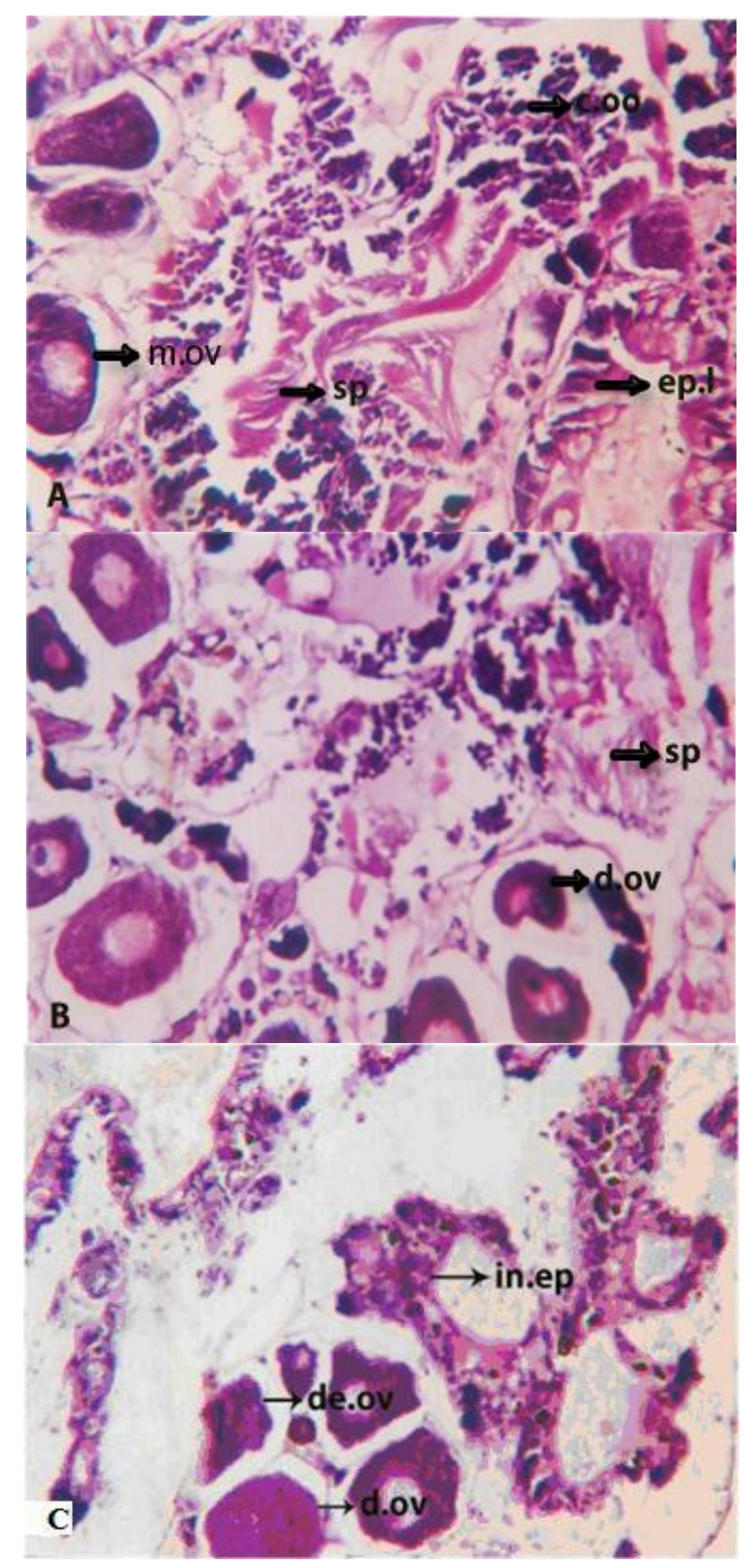

Plate 2: Sections of ovotestis of Physa acuta .

A- Control showing mature ovum(m.ov),ovotestis acinus(ovt.ac.),squamous sheath(s.sq.),sperms(sp),cluster of oogonia(c.oo.), and epithelial lining(ep.l.).

B- Exposure for two weeks, showed degenerated sperms (d.sp.), degeneratd ovum (d.ov.) and invaginated epithelium (in.ep.).

C- Exposure to four weeks, showing degenerated sperms (de.sp.), dead ovum (d.ov.), and empty acinus (e.ac.). 


\section{El-feky et al}

\section{Discussion}

Tributyltin oxide TBT is an organotin compound used as preservative for wood, cotton, textiles, paper, and paints. It is also used as an antifouling agent in boats, ships quays, buoys, crab pots, fish nets, and cages, by protecting these surfaces and structure from the growth of mollusks and other marine organisms.

TBT has been used as an additive in paint and wood preservative to prevent the growth of mold and mildew, but was banned in 1988 from interior house paints because of the hazards it posses to human. Many countries have restricted the use of TBT as antifouling agent. In the developing countries like Egypt, it is still used as antifouling agent especially in pleasure boating activity and fish nets in Nile River.

The banning of TBT compounds was not taken in consideration as it should be, so use of such materials may have a delayed effect on the fauna and flora of Nile River in the long run. The current study was designed to investigate the effect of TBT on two common species of freshwater snails (Physa acuta and Lymnea natalensis) inhabiting the River Nile and its branches, and the use of these invertebrates as bioindicators. The main source of TBT to the studied snails is the aquatic algae they feed on, beside the water source due to the life style of these two species of crawling on mud. Very little information is available on TBT effect on the physiological state of the invertebrates. However, the current work was trying to understand the effect of TBT on physiological status of these snails. The study focused on different physiological parameters which have an intimate relation to the development of gonads.

The depletion in glucose content in heamolymph of the exposing snails for two weeks indicates its rapid utilization as an energy reserve in a form of stored glycogen due to stress condition. This agrees the opinion of Amr (2004). After exposure for a period of four weeks, glucose values tended to increase. This action may be due to under hypotoxic conditions, animals derive their energy from anaerobic breakdown of glucose which was available to the cells by increased glycogenolysis ( Pankaj and Ajay, 2004).

Arthur (1987) had suggested that catecholamine levels rise under stressful environmental conditions, enabling the increased utilization of glycogen for energy production, so glucose value appeared to increase in the snail heamolymph.

The concentration of heamolymph cholesterol of both Physa and Lymnea snail after exposure to TBT for two weeks significantly increased. This increase may be due to the change of the physiological adaptation under TBT stress. This is because in stress situation, the animal requires high energy where the tissue released its stored cholesterol to the circulating plasma. After exposure for four weeks the concentration of cholesterol was highly decreased due to its utilization by the animal under continuous stress ( Vink et al., 1995 and Amr, 2004).

Both species had different behavior about the effect of TBT on the $\mathrm{Ca}^{+2}$ concentration of hemolymph. The results indicated that Physa snails showed highly increased level of $\mathrm{Ca}^{+2}$ after exposure for two weeks, then this concentration decreased after 4 weeks of exposure in the same snail. This indicated that TBT (hormonal disruptor) caused disruption of normal metabolic pathway as an antistress response (Puccia et al., 2001).

In the other hand, $\mathrm{Ca}^{+2}$ concentrations significantly decreased after exposure for two and four weeks in the case of Lymnea snails. The results of Suzoki et al. (2006) respected the same influences on Physa snails; they indicated that the plasma $\mathrm{Ca}$ and hypocalcimic hormones levels increased in Gold fish kept in water containing TBT.

Proteins are the most important and abundant macromolecules in the living beings, playing a vital role in the architecture and physiology of the cell and in cellular metabolism (Mommsen and Walsh., 1992).

Total proteins concentration of hemolymph of both species, Physa and Lymnea indicated confused results, where in physa its concentration remained constant after exposure for two weeks but it highly 
increased after four weeks of exposure. Lymnea snails exhibited different reactions then increased to the same concentration as control after four weeks of exposure. Ribeiro et al. (2001); and Amr (2004) showed differed results where they indicated gradual decrease in the total proteins concentration after exposure to TBT.

In the other hand, Ghosh and Chatter Jee (1989) and El-Emam and Ebeid (1989) observed an increase of total protein concentration due to stress, they suggested that the increase in protein was most probably resulting from increase in lypolyses damage to cellular organization which give false indication coming from the damaged tissues within the snails.

On the other hand, the depletion of the protein fraction in the hemolymph of the snails in this experiment may be due to protein degradation for metabolic purposes. Under stress conditions, the dietary protein consumed by snails is not stored in the body tissue (Baskaran and Palanichamy, 1990) and hence the treated snails met their extra energy requirements from body proteins which are mobilized to produce glucose, the instant energy of which is made available for the snail by the process of gluconeogenesis (Vasanthi et al., 1990). Thus, the decreased protein content may be attributed to the destruction/necrosis of cells and consequent impairment in protein synthesis machinery (Bradbury et al., 1987).

Albumin concentration in the hemolymph of Physa showed a significant increase after two weeks of exposure to TBT then decreased to the control level after four weeks of exposure. In the same time, globulin concentration decreased after exposure for two weeks in both snails, then highly increased after four weeks of exposure in Physa, and still as control in Lymnea snail.

All these parameters influenced by the change of various hormones secreted by endocrine glands which already influenced by TBT (hormonal disruptor agent). These hormones alter the balance between the tissue and plasma protein.

The exposure of aquatic organisms to even very low levels of pesticides in their environment may result in various where total proteins concentration significantly decreased after two weeks and biochemical, physiological and histological alterations in vital tissues of aquatic organisms( Kulshrestha and Arora, 1984; Jonnalagadda and Rao, 1996; Bhavan and Geraldine, 2000 Cengiz et al., 2001; Cengiz and Ünlï, 2002; Çaliskan et al., 2003; Dutta and Arends, 2003).).

The two species of snails (Physa acuta, and lymnea natalensis) showed different changes in their ovotestis after exposure to TBT for two and four weeks period. The acini of ovotestis revealed marked disturbances in differention and maturation processes. After exposure for a long time, the ovotestis exhibited not only a severe disruption of germ cells formation but also reduction in the intensity of sperms and follicles within the acini. Cells degeneration also occurred, symptoms of atrophy appeared. The provious results showed complete agreement with the foundation of Schulte-oehlmann et al. (2000); and Amr (2004).

\section{References:}

Amr FA (2004): Biological studies on the use of some invertebrates as bioindicator of pollution by one of oil drevatives. M.Sc. Thesis. Faculty of Science, Al-Azhar University, Egypt.

Arthur CG (1987): Human Physiology and Mechanisms of Disease. W. B. Saunders Company.Library of Congress catalog card number 86-15530.London.

Baskaran P and Palanichamy S (1990): Impact of agricultural (ammonium chloride) fertilizer on physiology and biochemistry of fresh water teleost fish, Oreochromis mossambicus. J. Ecobiol., 2: 97-106.

Bech M (2002): A survey of imposex in muricids from 1996 to 2000 and identification of optimal indicators of tributyltin contamination along the east coast of Phuket island, Thailand. Mar.Pollut. Bull., 44: 887896.

Bhavan PS and Geraldine $P$ (2000): Histopathology of the hepatopancreas and gills of the prawn Macrobrachium malcolmosonii exposed to endosulfan. Aquat. Toxicol., 50: 331-339.

Bradbury S; Makim JR and Coats JR (1987): Physiological responses of rainbow trout, Salmo gairdneri to acute fenvalerate intoxication. Pestic. Biochem. Physiol., 27: 275-285. 
Bryan G W; Gibbs P E; Hummerstone L G and Burt GR (1986): The decline of the gastropod Nucella Lapillus around South-West England : Evidence for the effect of tributyltin gills of common guppy Lebistes reticulatus. Environ. Toxicol. Pharmacol., 14:117-120.

Cengiz EI and Ünlü E (2002): Histopathological changes in the gills of mosquitofish, Gambusia affinis exposed to endosulfan. Bull. Environ. Contam. Toxicol., 68: 290-296.

Cengiz EI; Ünlü E and Balci K (2001): The histopathological effects of thiodan on the liver and gut of mosquitofish, Gambusia affinis. J. Environ. Sci. Health ,36: 75-85.

Cowley D M; Mcwhinney B C; Brown J M and Chalmers A H (1987): Chemical factors important to calcium nephrolithiasis: evidence for impaired hydroxycarboxylic acid absorption causing hyperoxaluria.Clin. Chem., 33: 243247.

Doumas B T (1975): Standards for total serum protein assays. Acollaborative study.Clin.Chem., 21(8): 1159-1161.

Dutta HM and Arends DA (2003): Effects of endosulfan on brain acetylcholinesterase activity in juvenile bluegill sunfish. Environ. Res., 91:157-162.

El-Emam $M$ A and Ebeid FA (1989): Effect of Schistosoma mansoni infection, starvation and molluscicides on acid phosphatase, trasaminases and total protein in tissues and hemolymph of Biomphalaria Alexandria. J. Egypt Soc. Parasitol., 19(1): 139147.

Fent K (1996): Ecotoxocology of organotin compounds , Critical Review in Toxicology, 1:117.

Galloway T S; Josephine A and Michael H D (2004): Toxicity of Tributyltin in the marine mollusk Mytilus edulis. Marine Pollution Bulletin, 51: 811-816.

Gibbs $P$ E and Bryan GW (1996a): Reproductive failure in the gastropod Nucella lapillus associated with imposex caused by tributyltin pollution: A review: organotin: Environmental Fate and Effects. Champ M.A and PF Seligman (Eds). Chapman and Hall, London, 259-280.

Ghosh T K and Chatterjee S K (1989): Influnce of Nuvan on the organic reserves of Indian fresh water murrel Channa punctatus.J. Environ.Biol., 10: 93-99.

Gooding M P; Gallardo C S and Leblanc G.A (1999): Imposex in three marine gastropod species in Chile and potential impact on muriciculture. Mar. Poll. Bull., 38: 1227-1231. from antifouling paints. J. Mar.Bio. Ass., 66: 611-640.

Çaliskan M; Erkmen B and Yerli S V (2003): The effects of zeta cypermethrin on the

Grosell M and Brix VK (2004): High net calcium uptake explains the hypersensitivity of the fresh water pulmonate snail, Lymnaea stagnalis, to chronic lead exposure. Aquatic Toxicology, 91: 4-9.

Haggera JA; Depledge $\mathrm{M} H$ and Galloway T S (2005): Toxicity of (tributyltin) in the marine mollusc Mytilus edulis, Mar Pollut. Bull., 51: 811-816.

Hall Jr W; Scott M C; killen W D and Unger M A (2000): A probabilistic ecological risk assessment of tributyltin in surface waters of the Chesapeake Bay watershed. Human Ecol., 6: 141-179.

Harris H F (1990): Theory and Practice of Histological Techniques. Edited by Bancrafts, J.D. Stevens, A. and Dowson. J. Chrachill Livingstone, Edinburgh, London and New York, 84-89.

Heidrich D D; Steckelbroeck S and klingmulle D (2001): Inhibition of human cytochrome P450 aromatase activity by tributyltins. Steroids, 66: 763-769.

Hugget R J; Kimerle R A; Mehrie P M and Bergman H L (1992): Biomarkers: Biochemical Physiological and Histological Markers of Anthropogenic Stress. Lewis Publishers, London.

Ide I Witten E P; Fischer J; Kalbfus W; Zellner A; Stroben $\mathbf{E}$ and Watermann B (1997): Accumulation of organotin compounds in common whelk Buccinum undatum and the red whelk Neptonea antiqua in association with imposex. Marine ecology progress Series, 152: (1-3): 197-203.

Jonnalagadda P R and Rao B P (1996): Histopathological changes induced by specific pesticides on some tissues of the fresh water snail, Bellamya dissimilis Müll. Bull. Environ. Contam. Toxico., 57: 648-654.

Keilin D and Hartree E F (1945): The use of glucose oxidase for the determination of glucose in biological material and for the study of glucose-producing systems by manometric methods.Biochem.,39: 148-152.

Kulshrestha S K and Arora N (1984): Impairments induced by sublethal doses of two pesticides in the ovaries of a freshwater teleost Channa striatus Bloch. Toxicol. Lett., 20: 9398.

LeBlance G (1999): Acute Toxicity of Tributyletin oxide to Daphnia magna .US EPAOPP Regestration Standard.

Leung K M Y; Grist E P M; Morley N J; Morritt D and Crane M (2007): Chronic toxicity of (tributyltin) to development and 
reproduction of the European freshwater snail Lymnaea stagnalis (L.), Chemosphere, 66: 1358-1366.

Lira CRS De; Gomes E M; Chagas G M and Pinheiro J (2000): Influencia do jejum severo sobre o conteudo de proeinas totais e de amoniom na hemolinfa de bradybaene similaries(ferussac, 1821)(Gastropod) Rev. Bras. Zool., 17 : 913.

Marcillo Y and Porte C (1999): Evidence of endocrine disruption in the imposex-affected gastropod Bolinus brandaris. Environ. Res., 81: 349-354.

Marshall D J and Rajkumar A (2003): imposex in the indigenous Nassarius kraussianus (mollusca: Neogastropoda) from South Africa harbours. Mar.Pollut. Bull., 46: 1150-1155.

Meador J P (1997): Comparative toxicokinetics of tributyltin in five marine species and its utility in predicting bioaccumulation and acte toxicity. Aqua.Toxicol., 37(4): 307-326.

Mommsen T P and Walsh P J (1992): Biochemical and environmental perspectives on nitrogen metabolism in fishes. Experientia, 48: 583-593.

Pankaj K T and Ajay S (2004): Carbaryl induced alterations in the reproduction and metabolism of fresh water snail Lymnaea acuminate. Pesticide Biochemistry and Physiology, 79: 1-9.

Puccia E; Mansueto C; Cangiolosi M V; Fiore T; Di Stefano R; Pellertio C; Triolo F and Pellerito L (2001): Organometalic complexes with biological molecuoles. XV. Effect of tributyltin (IV) chloride on enzyme activity, ca2+, and biomolecule and synthesis Ciona intestinalis (urochordata) ovary. Appl. Organometal. Chem., 15: 213-220.

Ribeiro S; Sousa J P; Nogueira A J A and Soares A M M (2001): Effect of endosalfan and parathionon energy reserves and physiological parameters of the tresterial isopod Porcellio dilatatus .Ecotoxic. Environ. Safety, 49: 131138.

Richmond W (1973): Preparation and properties of cholesterol oxidase from Nocardia $s p$. And its application to the enzymatic assay of total cholesterol in serum. Clin. chem., 19: 13501356.

Schulte-oehlmann U; Tillmann M; Markert B and Oehlmann J (2000): Effects of endocrine disruptors on prosobranch snails (Mollsca Gastropod) in the laboratory. Part 11 : triphenyltin as a xeno-androgen. Ecotoxicology, 9: 399-412.

Suzoki T; Takahashi N; Fukunaga K; Okamura M; Tanaka T; and Takama K (2006): Intoxication of euglena cells by tributyltin chloride and its detoxication by pretreatment with high electric field loaded water. Environ. Toxicol. Water. Qual., 8 (2): 207-222.

Terlizzi A; Delos A L; Garaventa F; Faimali $M$ and Geraci S (2004): limited effectiveness of marine protected areas: imposex in Hexaplex trunculus (Gastropoda: Muricidae) populations from Italian marine reserves. Mar.pollut. Bull., 48: 188- 192.

Toshihiro H; Mistuhiro K; Fumihiko H; Akira K; Hiroaaki S; Masatoshi $M$ and Makoto S (2006): Impact of Tributyltin and Triphenyltin on lvory shell(Babylonia japonica) Populations. Environmental Health Perspectives, 45:114-119.

Vasanthi R; Baskaran $P$ and Palanichamy $S$ (1990): Influence of carbofuran on growth and protein conversion efficiency in some fresh water fishes. J. Ecobiol., 2: 85-8.

Vasseur $P$ and Cossu-Leguille $C$ (2003): Biomarkers and community indices as complementary tools for environmental safety. Environ.Int., 28: 711-717.

Vink K; Dewi J; Bedaux J; Tompot M H and Van Straalen N M (1995): The importance of the exposure route when testing the toxicity of pesticides to saprotrophic isopods. Environ. Toxicol. Chem., 14: 1225-1232.

Widdows J and Dankin P (1992): Mussels and Environmental Contaminants: Bioaccumulation and Physiological Aspects. In: Gosling, E. (Ed), The Mussel Mytilus: Ecology, Physiology, Genetics and Culture, first ed. Elsevier, London, 383-424. 


\section{التأثيرات الفسيولوجية والهستولوجية لثلاثى بيوتيل القصدير على قوقعى ليمنيا}

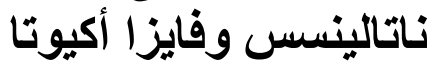

$$
\begin{aligned}
& \text { فاتن الفقى, هبة الله رأفت } 1 \text {, حنان كمال1 } 1 \text { البان }
\end{aligned}
$$

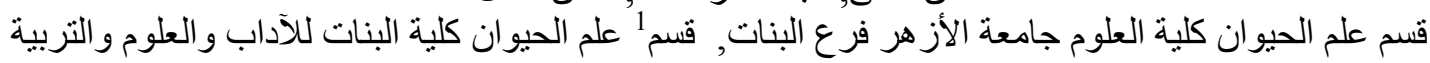

$$
\begin{aligned}
& \text { جامعة عين شمس, القاهرة. }
\end{aligned}
$$

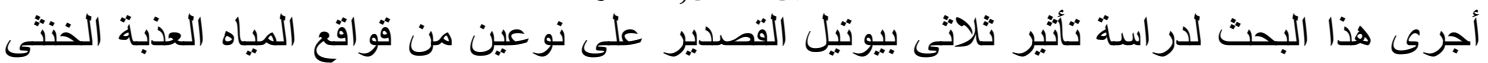

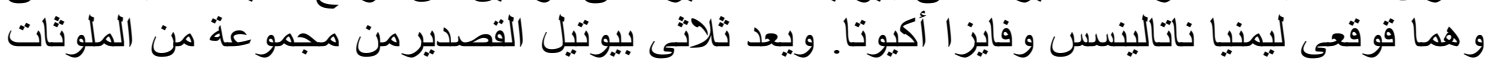

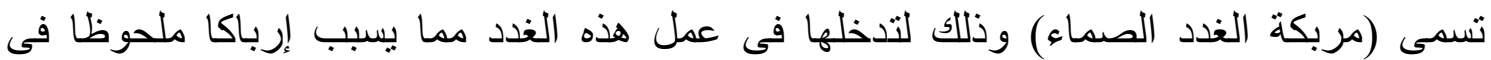

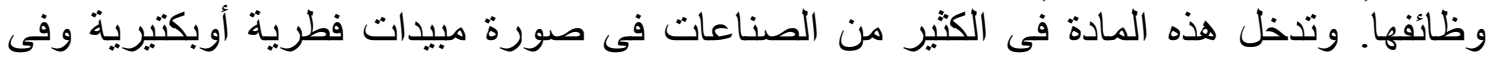

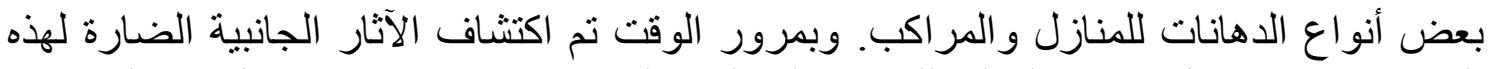

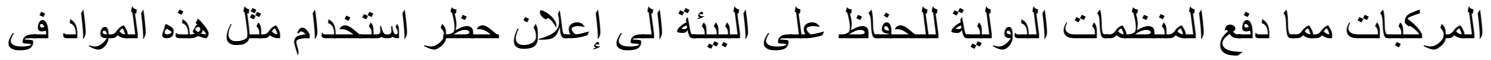

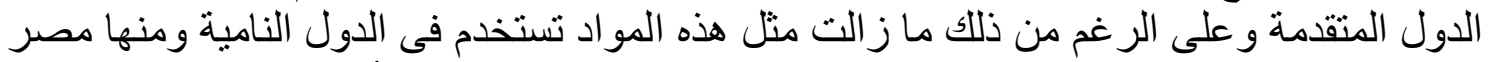

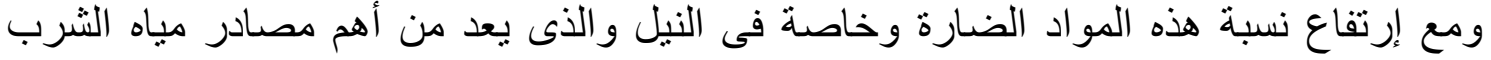

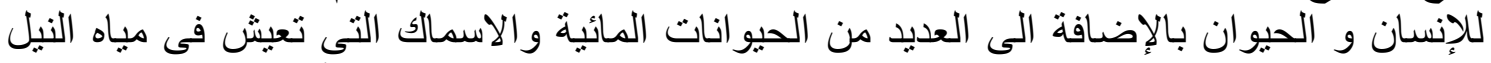

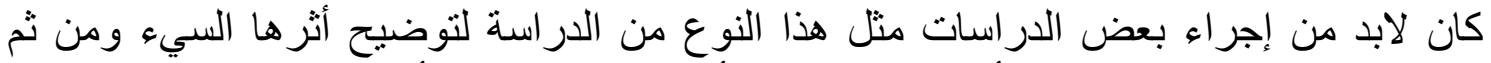

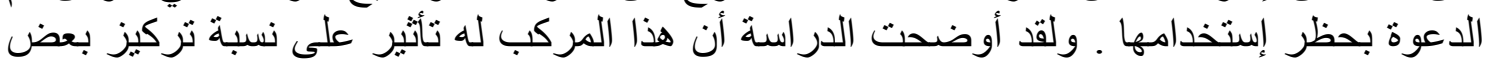

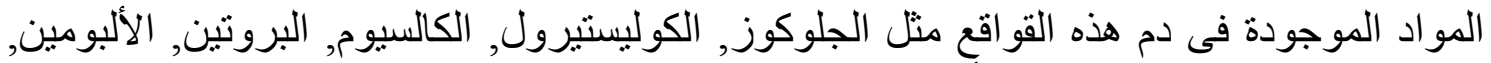

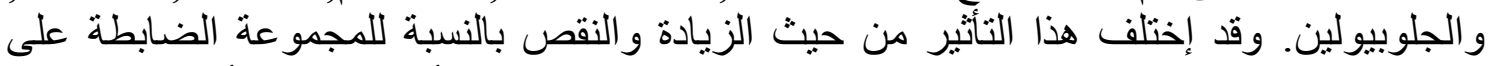

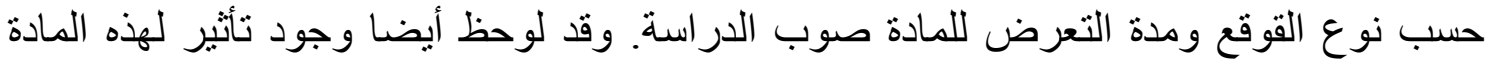

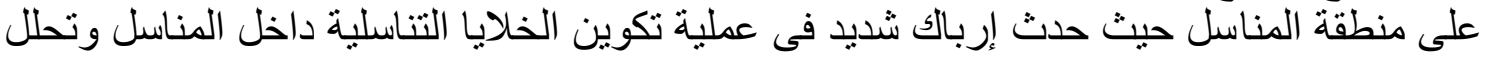

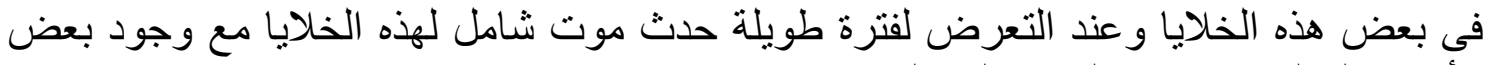
الأماكن الخالية تماما من الخلايا التناسلية. 